\title{
Effects of dietary allspice, Pimenta dioica powder on physiological responses of Oreochromis mossambicus under low pH stress
}

\author{
Sevdan Yılmaz', Ümit Acar ${ }^{2 *}$, Osman Sabri Kesbiç3 ${ }^{3}$, Nejdet Gültepe ${ }^{4}$ and Sebahattin Ergün ${ }^{1}$
}

*Correspondence:

umitacar@mu.edu.tr

${ }^{2}$ Department of Aquaculture,

Faculty of Fisheries, Muğla

Sıtkı Koçman University,

Muğla 48000, Turkey

Full list of author information

is available at the end of the article

\begin{abstract}
This study investigated the effects of the supplementation with allspice $(0,5,10,15$, or $20 \mathrm{~g} \mathrm{~kg}^{-1}$ ) on the haemato-immunological and biochemical variables in tilapia, Oreochromis mossambicus under acidic stress condition. In a 60-day feeding trial, 15 aquariums (80-L) were stocked with 18 fish $(20.05 \pm 0.10 \mathrm{~g})$ each. Then, acidic stress was achieved by exposing the sampled fish to acidic water ( $\mathrm{pH}$ 5.5) for 3 days. Allspice supplementation influenced the haematological indices, serum glucose, protein, globulin and innate immune parameters such as respiratory burst activity, lysozyme, and myeloperoxidase activities. In general, at acidic pH decreased circulating red blood cell numbers (RBC), increased mean corpuscular volume (MCV), mean corpuscular hemoglobin $(\mathrm{MCH})$ and the innate immune parameters were observed. On the other hand, the inclusion of allspice prevented an increase in blood glucose MCV and MCH, decreases in albumin, RBC, lysozyme activity and respiratory burst avtivity. In conclusion, this study demonstrated that allspice supplementation at $10 \mathrm{~g} \mathrm{~kg}^{-1}$ for 60 days, has adequate beneficial effects on improvement of haemato-immunological and biochemical status of $O$. mossambicus after stressful management.
\end{abstract}

Keywords: Tilapia, Plant, Supplementation, Biochemistry, Hematology

\section{Background}

In an outdoor aquaculture system, fish are usually exposed to physical and chemical stressors, such as fluctuations in water oxygen, temperature and $\mathrm{pH}$. Rapid fluctuations in $\mathrm{pH}$ are generally more problematic for fish than specific individual $\mathrm{pH}$ values (Roberts and Palmeiro 2008). Tilapia is less tolerant to water $\mathrm{pH}$ and may develop physiological changes following transfer from neutral water to acidic water (El-Sayed 2006). Low or high water $\mathrm{pH}$ may lead to behavioural changes, damage of gill epithelial cells, reduction in the efficiency of nitrogenous excretion and increased mortality of Oreochromis niloticus and O. mossambicus (Yada and Ito 1997).

Among nutritional antioxidants, it has been reported that vitamins $\mathrm{C}$ (ascorbic acid), $\mathrm{E}$ ( $\alpha$-tocopherol) and B6 (pyridoxine $\mathrm{HCl}$ ) play a beneficial role in ameliorating stressful conditions in sea bream (Sparus aurata), tilapia (O. niloticus) and hybrid catfish (Clarias

\section{望 Springer}

(c) 2015 Yllmaz et al. This article is distributed under the terms of the Creative Commons Attribution 4.0 International License (http:// creativecommons.org/licenses/by/4.0/), which permits unrestricted use, distribution, and reproduction in any medium, provided you give appropriate credit to the original author(s) and the source, provide a link to the Creative Commons license, and indicate if changes were made. 
macrocephalus $\times$ C. gariepinus) (Montero et al. 1999; Pitaksong et al. 2013). In addition, it is known that herb extracts Rheum palmatum and R. rebis could increase the resistance to high temperature stress in Kutum fish (Rutilus frisii kutum) (Babak et al. 2012a, b).

Allspice (Pimenta dioica) has been used in traditional folklore medicine for several hundreds of years (Nayak and Abhilash 2008). It can be used to remedy poor appetite, chills, diarrhea, dyspepsia, high blood sugar, and rheumatism (Mars 2007). Allspice has also been shown to have antioxidant (Kikuzaki et al. 1999) and antimicrobial properties (Du et al. 2009). Moreover, some studies indicate significant cytoprotective activities of allspice (Du et al. 2009; Nayak et al. 2008). For this reason, allspice is appearing a good feed additive and it can be used for ameliorating stressful conditions. According to this, the objective of this study was to evaluate the effect of allspice on the haemato-immunological and biochemical status of tilapia, O. mossambicus after acidic stress.

\section{Methods}

\section{Experimental fish and culturing conditions}

Healthy cultured $O$. mossambicus (mean weight $\pm \mathrm{SD}=20.05 \pm 0.10 \mathrm{~g}$ ) were produced in the laboratory of Fisheries Faculty of Çanakkale Onsekiz Mart University (Çanakkale, Turkey). The temperature and dissolved oxygen of the water were measured with a YSI Pro2030 probe, and pH was measured with a HANNA (Model HI 2221; Hanna Instruments, USA) photometer. Total ammonia, nitrite and nitrate were determined by spectrophotometry using Merck test kits and measured by a Optizen POP UV/VIS Spectrophotometer. During the experiment, water quality characteristics (mean $\pm \mathrm{SE}$ ) were as follows: temperature was $27 \pm 0.5^{\circ} \mathrm{C}$, pH was $7.2 \pm 0.2$, dissolved oxygen was $7.5 \pm 0.2 \mathrm{mg} \mathrm{L}^{-1}$, conductivity was $595 \pm 10 \mathrm{uS}$, total $\mathrm{NH}_{3}$ was $0.09 \pm 0.02 \mathrm{mg} \mathrm{L}^{-1}$, nitrite was $0.03 \pm 0.01 \mathrm{mg} \mathrm{L}^{-1}$ and nitrate was $1.1 \pm 0.3 \mathrm{mg} \mathrm{L}^{-1}$ throughout the experiment. Fish experiments were performed in accordance with the guidelines for fish research from the animal ethic committees at Çanakkale Onsekiz Mart University.

\section{Experimental herb and diets}

Allspice (P. dioica) seed meal was obtained from Kotanyi, GmbH (Istanbul, Turkey). It was added to the feed at a rate of $0,5,10,15$ and $20 \mathrm{~g} \mathrm{~kg}^{-1}$. The feed components of the diets are presented in Table 1. The ingredients were mixed in a mixer. The feed was pressed through a $2-\mathrm{mm}$ die in a pelleting machine, and the pellets were dried in a drying cabinet $\left(40^{\circ} \mathrm{C}\right)$ until moisture dropped to around $10 \%$. The pellets were crushed into desirable particle sizes and stored at $-20{ }^{\circ} \mathrm{C}$ until use.

\section{Experimental design and feeding trial}

Fifteen $80-\mathrm{L}$ aquarium were stocked with 270 fish (18 fish per aquarium, three replicates). To acclimatize the tilapia to the experimental conditions, the fish were fed the basal diet for 2 weeks. The experimental fish were fed to apparent satiation twice a day for 60 days. Each aquarium was provided with sponge filters connected via airline to a Resun LP-100 air pump. During the experiment, water was exchanged daily at a rate of $\sim 10 \%$ of the total volume. 
Table 1 Formulation of experimental diet (36\% crude protein, $10 \%$ fat)

\begin{tabular}{ll}
\hline Ingredients & Concentration (g//kg) \\
\hline Fish meal $^{\mathrm{a}}$ & 280.0 \\
Soybean meal $^{\mathrm{a}}$ & 320.0 \\
Wheat flour $^{\mathrm{a}}$ & 262.0 \\
Fish oil $^{\mathrm{a}}$ & 65.0 \\
Vitamin-mineral mix $^{\mathrm{b}, \mathrm{c}}$ & 40 \\
Starch $^{\mathrm{d}, \mathrm{f}}$ & $33.0-13.0$ \\
Allspice & $0-20$
\end{tabular}

a Anchovy fish meal, soybean meal, wheat flour and anchovy fish oil. Sibal Inc., Sinop, Turkey

b Vitamin mix: Vit. A 18,000 IU, Vit D3 2500 IU, Vit. E 250 mg/kg, Vit. K3 12 mg/kg, Vit. B1 25 mg, Vit. B2 50 mg, Vit. B3 270 mg, Vit. B6 20 mg, Vit. B12 0.06 mg, Vit. C 200 mg, folic acid 10 mg, calcium d-pantothenate 50 mg, biotin 1 mg, inositol $120 \mathrm{mg}$, choline chloride $2000 \mathrm{mg}$

c Mineral mix: Fe 75.3 mg, Cu 12.2 mg, Mn 206 mg, Zn 85 mg, I 3 mg, Se 0.350 mg, Co 1 mg

d Wheat starch. Kenton, Ankara, Turkey

e Allspice. Kotanyi, GmbH, Istanbul, Turkey

f The same diet modified by replacing starch with different amounts of allspice to give $5,10,15$ and $20 \mathrm{~g} / \mathrm{kg}$

\section{Acidic stress}

Fish were not fed for $24 \mathrm{~h}$ before exposing them to acidic water. All group of fish were subjected to stress. Nine fish from per group (three fish per aquarium) were used to haematological, biochemical and immunological evaluations. An acidic stress was achieved by exposing the sampled fish to acidic water ( $\mathrm{pH} 5.5$ ) for 3 days. Aquarium $\mathrm{pH}$ was measured with a digital Hanna instruments pH meter (HI 2221).

\section{Blood collection}

In the experiment, 9 fish on the 60th day were used for blood sampling in control group. To Balance number of fish in groups, 9 fish from each group were excluded from the trial. After the acidic stress experiment, blood sampling was conducted to assess the effects of dietary allspice on haematological variables under stressful conditions. In addition, the blood stress indicators, including blood glucose, serum protein, albumin and globulin, and innate immune parameters of the fish were examined. Fish from each diet anesthetized with clove oil. Blood samples were collected from the caudal vein using a syringe. And the blood was added to tubes containing EDTA $10 \%$ (BD Microtainer ${ }^{\circledR}$, UK). Blood serum was separated by centrifugation $(4000 \times g, 10 \mathrm{~min})$ in plastic biochemistry tubes (Kima-vacutest ${ }^{\circledR}$, Italy) and stored at $-20{ }^{\circ} \mathrm{C}$ until used for biochemical analysis (Bricknell et al. 1999).

\section{Hematological analysis}

Red blood cells $\left(\mathrm{RBC}, 10^{6}\right.$ per $\left.\mathrm{mm}^{3}\right)$, hematocrit (Hct, \%) and hemoglobin $\left(\mathrm{Hb}, \mathrm{gdL}^{-1}\right)$ was determined using the method of Blaxhall and Daisley (Blaxhall and Daisley 1973). RBC was counted with a Thoma hemocytometer using Dacie's diluting fluid. Hct was determined using a capillary hematocrit tube. Hb concentration was determined by spectrophotometry $(540 \mathrm{~nm})$ using the cyanomethahemoglobin method. Mean corpuscular volume $(\mathrm{MCV})$, mean corpuscular hemoglobin $(\mathrm{MCH})$, and mean corpuscular hemoglobin concentration $(\mathrm{MCHC})$ were calculated using the following formulas (Bain et al. 2006). 


$$
\begin{aligned}
& \operatorname{MCV}\left(\mu \mathrm{m}^{3}\right)=[(\mathrm{Hct}, \%) \times 10] /\left(\mathrm{RBC}, \times 10^{6} \mathrm{per} \mathrm{mm}^{3}\right) \\
& \operatorname{MCH}(\mathrm{pg})=[(\mathrm{Hb}, \mathrm{g} / \mathrm{dL}) \times 10] /\left(\mathrm{RBC}, \times 10^{6} \text { per } \mathrm{mm}^{3}\right) \\
& \operatorname{MCHC}(\%)=[(\mathrm{Hb}, \mathrm{g} / \mathrm{dL}) \times 100] /(\mathrm{Hct}, \%)
\end{aligned}
$$

\section{Biochemical analyses}

Biochemical indices in serum including glucose (GLU), total protein (Tprot), albumin (ALB) and globulin (GLO) were determined using bioanalytic test kits (Bioanalytic Diagnostic Industry, Co) and measured by a shimadzu spectrophotometer (PG Instruments, UK). Serum globulin was determined by the following formula: Globulin = total protein - albumin.

\section{Immunological analyses}

\section{Respiratory burst activity (NBT assay)}

The respiratory burst activity (RBA) of the neutrophils and monocytes was quantified by the reduction NBT (nitroblue tetrazolium) to formazan as a measure of the production of oxygen radicals. $0.1 \mathrm{ml}$ of the blood from fish of each group was mixed with an equal amount of $0.2 \%$ NBT solution for $30 \mathrm{~min}$ at room temperature. After incubation $0.05 \mathrm{ml}$ of solution was taken from the NBT-blood cell suspension and added to a glass tube with $1 \mathrm{ml}$ of $\mathrm{N}, \mathrm{N}$ diethylmethyl formamide and then centrifuged at $3000 \times g$ for $5 \mathrm{~min}$. The optical density of the supernatant was measured at $540 \mathrm{~nm}$ (Siwicki and Anderson 1993).

\section{Lysozyme activity}

Serum lysozyme (Lyso) was assessed using the turbidometric assay (Ellis 1990). A suspension of $875 \mu \mathrm{L}$ of Micrococcus lysodeikticus (Sigma, ATCC 4698) at a concentration of $0.2 \mathrm{mg} \mathrm{mL}^{-1}$ (in PBS) and was added to $25 \mu \mathrm{L}$ of serum samples were measured spectrophotometrically at $530 \mathrm{~nm}$ after 0.5 and $4.5 \mathrm{~min}$ at $25^{\circ} \mathrm{C}$, using a spectrophotometer. A unit of lysozyme activity was defined as the amount of serum causing a reduction in absorbance of $0.001 \mathrm{~min}^{-1}$.

\section{Myeloperoxidase activity}

Total myeloperoxidase (MPO) content in serum was measured according to Quade and Roth (1997) with minor modifications. $30 \mu \mathrm{L}$ serum was diluted with $370 \mathrm{ml}$ of HBSS without $\mathrm{Ca}^{2}$ or $\mathrm{Mg}^{2}$ in eppendorf tubes. $100 \mu \mathrm{L}$ of $0.1 \mathrm{mg} / \mathrm{ml}$ 3,3',5,5'-tetramethylbenzidine dihydrochloride and $0.006 \%$ fresh hydrogen peroxide were added. The reaction was followed kinetically every $50 \mathrm{~s}$ for $4.5 \mathrm{~min}$. Reaction velocities were determined as IU, defined as the amount of enzyme required to produce an 0.001 increase in absorbance per minute $0.5 \mathrm{ml}$ of reaction mixture $(\Delta \mathrm{A} 450 / \mathrm{min} / \mathrm{mL})$.

\section{Statistics}

Each value was expressed as mean \pm Standart Error (SE) for each of the measured variables. The analyses were performed using SPSS 17.0 (SPSS Inc., Chicago, IL, USA). Statistical significance was established at $P<0.05$. 


\section{Results and discussion}

Haematological variables are good predictors for explaining the fish health status. The haematological characteristics of healthy fish vary according to internal and external factors (Teixeira et al. 2012; Faggio et al. 2015). The stressful condition significantly decreased RBC in fish that were fed the control diet, except diets that had been supplemented with 5-20 $\mathrm{g} \mathrm{kg}^{-1}$ allspice (Fig. 1). The results showed that acidic stress condition did not significantly change the levels of $\mathrm{Hb}$, Hct and $\mathrm{MCHC}$ (Fig. 1) in control group $(P<0.05)$. However, increasing $\mathrm{Hb}$ levels $(P<0.05)$ were obtained in supplemented diets with $15-20 \mathrm{~g} \mathrm{~kg}^{-1}$ allspice (Fig. 1 ). After acidic stress, Hct percentage was significantly higher $(P<0.05)$ in $20 \mathrm{~g} / \mathrm{kg}$ allspice group compared with control group (Fig. 1$)$. In addition, the dietary supplementation of $15 \mathrm{~g} \mathrm{~kg}^{-1}$ allspice showed the highest $(P<0.05)$ $\mathrm{MCHC}$ value among the all groups (Fig. 1). Fish that were fed with control diet showed significant increase $(P<0.05)$ in $\mathrm{MCV}$ and $\mathrm{MCH}$ (Fig. 1$)$ under stresfull conditions and supplemented diets with $5-10$ and $5-20 \mathrm{~g} \mathrm{~kg}^{-1}$ of allspice had lowering effects, respectively $(P<0.05)$.

In this study, there were signs of an impaired physiological condition caused by acid exposure and significantly changes in $\mathrm{RBC}, \mathrm{MCV}$ and $\mathrm{MCH}$. Decreased $\mathrm{RBC}$ (erythrocytopenia) and increased $\mathrm{MCV}$ and $\mathrm{MCH}$ were observed in fish after the acidic $\mathrm{pH}$, suggestiong a macrocytic normochromic anemia (Elahee and Bhagwant 2007). This anemia may be due to the inhibition of erythropoiesis and to an increase in the rate of erythrocyte destruction in hemopoietic organs (Adhikari et al. 2004). Our results showed the benefits of supplementation with $10 \mathrm{~g} \mathrm{~kg}^{-1}$ allspice to improve $\mathrm{RBC}, \mathrm{MCV}$ and $\mathrm{MCH}$

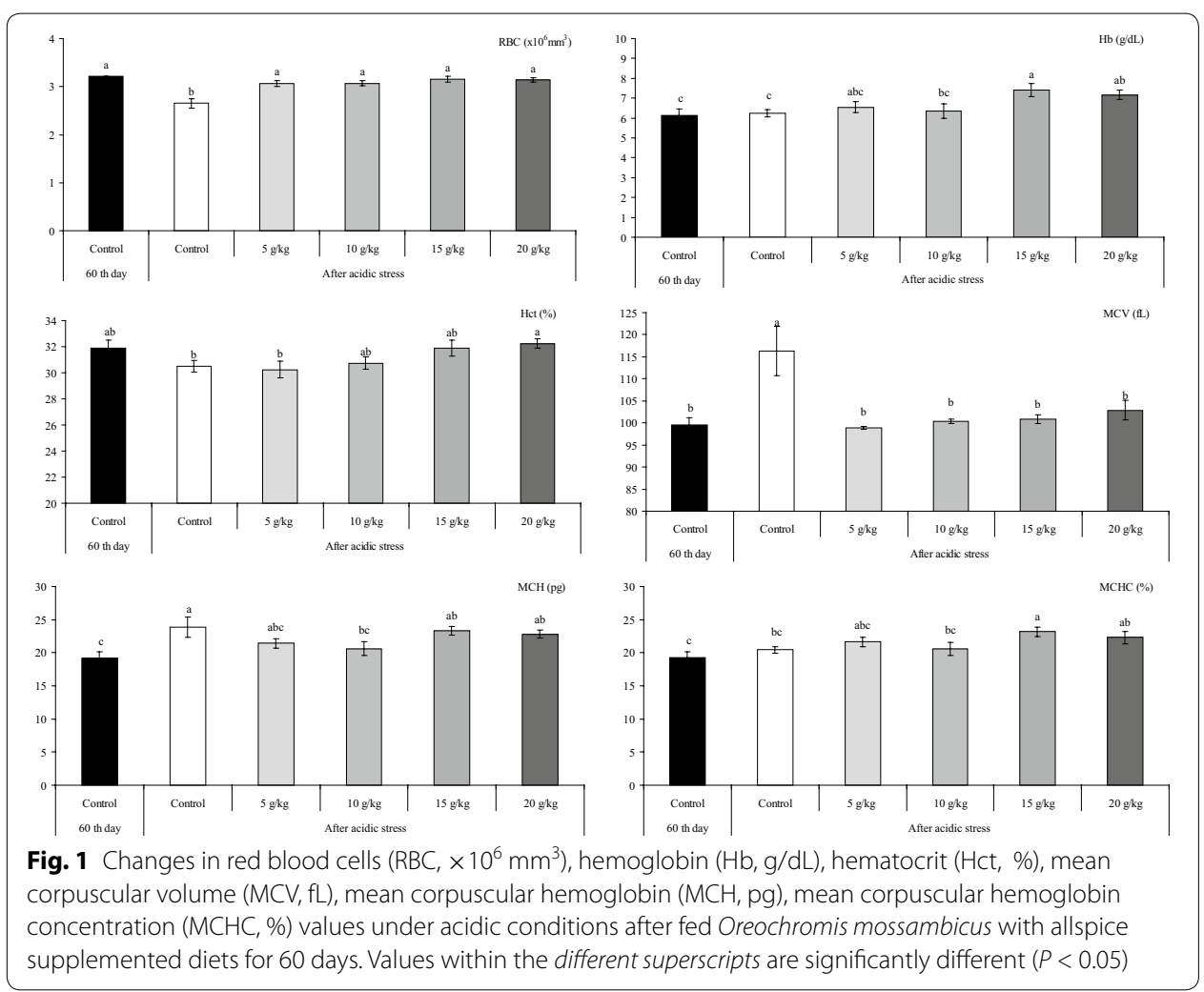


after acidic stress. Nayak and Abhilash (2008), also reported that the oral doses (250, $500,750 \mathrm{mg} / \mathrm{kg} /$ day) of allspice protect the haemoglobin from degradation in mice induced by cyclophosphamide. Hematoprotective effect can be related to the high total phenolic content in the leaves or berries of allspice (Nayak and Abhilash 2008; Nayak et al. 2008).

Significant negative associations among unsuitable water quality and fish physiological responses were observed in most of the studies. For example, Nussey et al. (2002), reported that at acidic $\mathrm{pH}$ copper and zinc concentrations negatively affected the hematological parameters (RBC, Hb, Hct, and $\mathrm{MCV}$ ), which can be ascribed to anemic and hypoxic conditions, gill damage and impaired osmoregulation of O. mossambicus. Similarly, the significant decrease in the number of RBCs, Hb, Hct and MCV of Tilapia soarrmanii after exposure to manganese at $\mathrm{pH} 5$ can be attributed to internal hemorrhaging that was observed (Wepener et al. 1992). Ghanbari and Jami (2012) and Das et al. (2006) also reported reductions in RBC and $\mathrm{Hb}$ after exposing carps, Cyprinus carpio, Catla catla, Labeo rohita and Cirrhinus mrigala to acidic water $\mathrm{pH}$. Similarly salinity affect the hematological parameters in cultured mullet, Mugil cephalus (Fazio et al. 2013).

Serum glucose has often been suggested as a useful nonspecific stress indicator (Evans et al. 2003). Our results showed slightly increase $(P>0.05)$ in serum glucose (Fig. 2). However, Pitaksong et al. (2013) reported that the acidic stress (pH 5.5 for $24 \mathrm{~h}$ ) increased the blood glucose levels in the hybrid catfish (C. macrocephalus $\times C$. gariepinus) fed control diet. The difference in these results may be due to the different fish species and/or application time used. The increase in serum glucose level and of the acidic $\mathrm{pH}$ treatment may be associated with glycogenesis to provide energy for the increased metabolic demands imposed by the acidic water. The change in water $\mathrm{pH}$ for fish might have caused the glycogen metabolism in the different organs like the gill and liver (Bhaskar and Govindappa 1985). Bhaskar and Govindappa (1985) reported that at the acidic $\mathrm{pH}$ the level of the gill glycogen and free glucose contents were lower in $O$. mossambicus. The glycogen content was elevated, suggesting increased glycogenesis or/ and decreased glycogenolysis (Bhaskar and Govindappa 1985), and thus has increase the conversion of liver glycogen to blood glucose to satisfy the greater energy demands of the body under stress (Miron et al. 2008). In this study, supplementation with $10 \mathrm{~g} \mathrm{~kg}^{-1}$ of allspice led to slightly decreasing in blood glucose under stressfull conditions. This can indicate that supplementation of allspice has minimized the stress responses of fish.

Serum total protein, albumin and globulin levels are also thought to be related to a stronger innate immune response in fish (Yllmaz and Ergün 2012). The results showed a slight decrease $(P>0.05)$ in total protein, albumin and globulin (Fig. 2$)$. However, the dietary supplementation with 5 and $10 \mathrm{~g} / \mathrm{kg}$ allspice increased the level of total protein and globulin in the acidic condition compared with the control group $(P<0.05)$.

The non-specific defence mechanisms play a key role in maintaining effective disease resistance to a variety of fish pathogens (Kiron 2012). Water environmental stressors, such as temperature, $\mathrm{pH}$, salinity etc. may also be affecting factors pathogenic microorganisms use to subvert the fish's immune response and cause disease (Dominguez et al. 2005). The stressful condition had the effect of reducing the respiratory burst activity in fish fed control diet $(P<0.05)$. Furthermore, the dietary supplementation with $10 \mathrm{~g} \mathrm{~kg}^{-1}$ allspice significantly increased $(P<0.05)$ the level of respiratory burst activity in acidic 


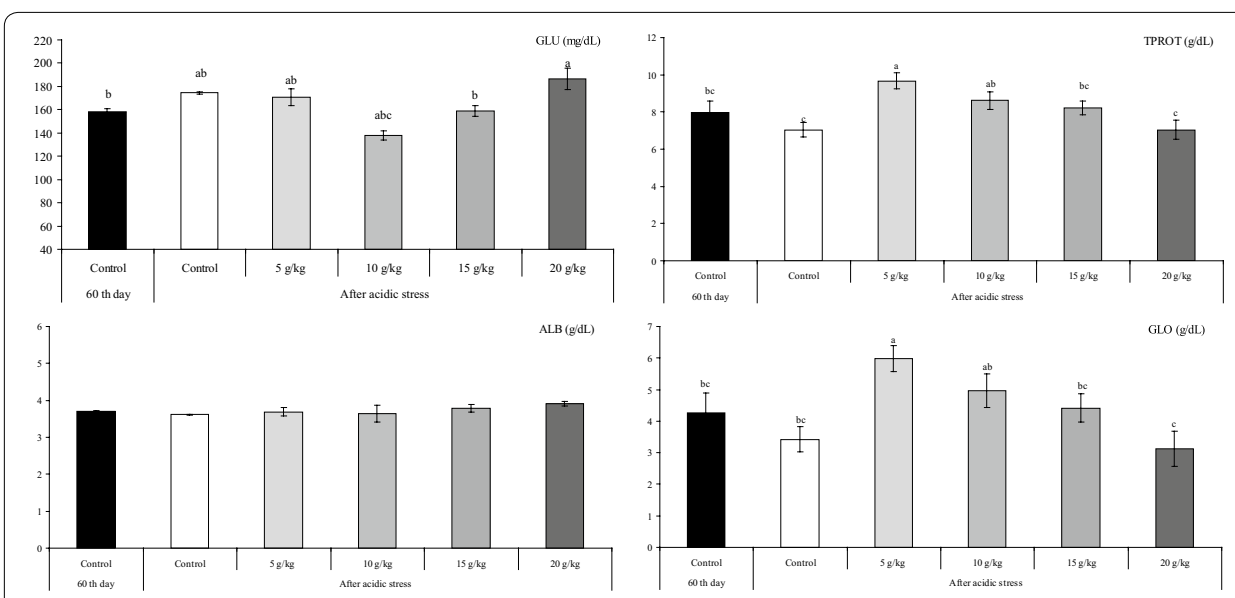

Fig. 2 Changes in glucose (GLU, mg/dL), total plasma protein (TPROT, g/dL), albumin (ALB, g/dL) and globulin $(\mathrm{g} / \mathrm{dL}$ ) levels under acidic conditions after fed Oreochromis mossambicus with allspice supplemented diets for 60 days. Values within the different superscripts are significantly different $(P<0.05)$

condition compared with the control group (Fig. 3). After acidic stress, the lysozyme was decreased in fish fed control diet $(P<0.05)$. The lysozyme level in stressed fish fed $5-20 \mathrm{~g} \mathrm{~kg}^{-1}$ allspice diets were also increased $(P<0.05)$ in acidic stress condition compared with the control diet (Fig. 3). The results showed that acidic stress conditions did not significantly changed $(P>0.05)$ the levels of myeloperoxidase (Fig. 3). However, the stressful condition significantly increased $(P<0.05)$ myeloperoxidase in fish fed $10-20 \mathrm{~g} \mathrm{~kg}^{-1}$ allspice diets compared with those fed control dietcontrol diet (Fig. 3). Similarly, a decrease in respiratory burst activity were reported in white shrimp L. vannamei following exposure to $\mathrm{pH} 6.5$ after 6-72 $\mathrm{h}$ indicating a decrease in the respiratory burst that might be related to a decrease in the production of $\mathrm{H}_{2} \mathrm{O}_{2}$ and leading to decreased catalase and peroxidase activities (Li and Chen 2008). Like the present study,

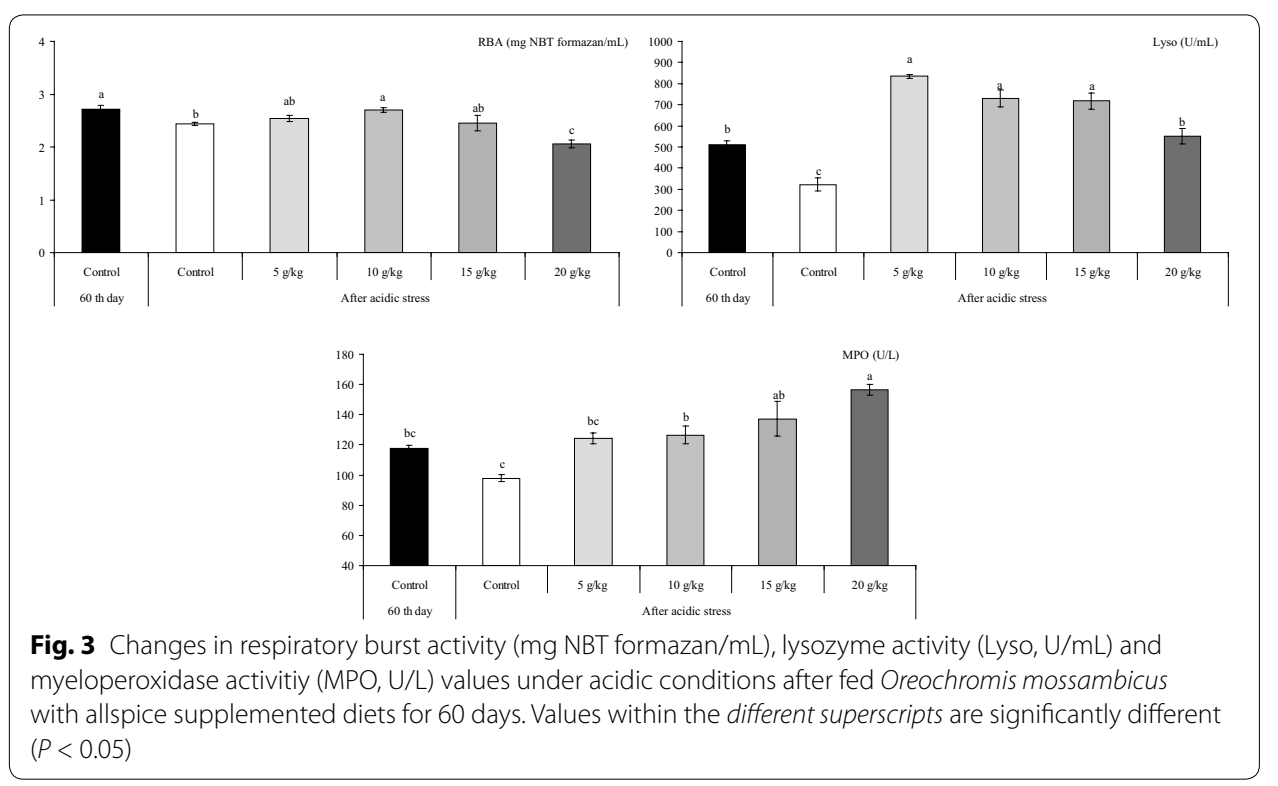


Pitaksong et al. (2013), reported that the acidic stress ( $\mathrm{pH} 5.5$ for $24 \mathrm{~h}$ ) had the effect of reducing the lysozyme activity in hybrid catfish $(C$. macrocephalus $\times C$. gariepinus) fed diets deficient of vitamin $\mathrm{C}$ and $\mathrm{E}$ for a period of 8 week. In contrast to our results, the increase in lysozyme activity by low $\mathrm{pH}$ (4.0) was reported in O. niloticus for a long term ( 2 weeks) acid induced (Dominguez et al. 2005). The difference in these results may be due to the different values of the $\mathrm{pH}$ used. Additionally, it is possible to suggest an interaction effects among time and $\mathrm{pH}$ on immune function.

\section{Conclusion}

The results of the present study demonstrated that allspice supplementation at $10 \mathrm{~g} \mathrm{~kg}^{-1}$ for 60 days, has adequate beneficial effects by improving the haemato-immunological and biochemical status of $O$. mossambicus after acidic stress.

\section{Abbreviations}

RBC: red blood cell; MCV: mean corpuscular volume; $\mathrm{MCH}$ : mean corpuscular hemoglobin; EDTA: ethylenediaminetetraacetic acid; Hct: hematocrit; Hb: hemoglobin; MCHC: mean corpuscular hemoglobin concentration; GLU: glucose; Tprot: total protein; ALB: albumin; GLO: globulin; RBA: Respiratory burst activity; NBT: nitroblue tetrazolium; Lyso: serum lysozyme; MPO: myeloperoxidase; HBSS: Hanks balanced salt solution.

\section{Authors' contributions}

SY: in the writing of the manuscript; ÜA: interpretation of data; OSK: in design and data analysis; NG: in design and data analysis; SE: in the writing of the manuscript. All authors read and approved the final manuscript.

\section{Author details}

${ }^{1}$ Department of Aquaculture, Faculty of Marine Sciences and Technology, Çanakkale Onsekiz Mart University, Çanakkale 17000, Turkey. ${ }^{2}$ Department of Aquaculture, Faculty of Fisheries, Muğla Sıtkı Koçman University, Muğla 48000, Turkey. ${ }^{3}$ Inebolu Vocational School, Sea and Port Management Program, Kastamonu University, İnebolu 37500, Kastamonu, Turkey. ${ }^{4}$ Department of Genetics and Bioengineering, Faculty of Engineering and Architecture, Kastamonu University, Kastamonu 38000, Turkey.

\section{Acknowledgements}

The authors thank Çanakkale Onsekiz Mart University, Marine Science and Technology Faculty to use their facility for the experiment.

\section{Competing interests}

The authors declare that they have no competing interests.

Received: 11 August 2015 Accepted: 9 November 2015

Published online: 24 November 2015

\section{References}

Adhikari S, Sarkar B, Chatterjee A, Mahapatra CT, Ayyappan S (2004) Effects of cypermethrin and carbofuran on certain hematological parameters and prediction of their recovery in a freshwater teleost, Labeo rohita (Hamilton). Ecotoxicol Environm Saf 58:220-226

Babak N, Reza IM, Ali S (2012a) Effects of Rheum palmatum L. root extract on the blood parameters in responses to two high heat stress and lipid oxidation of Rutilus frisii kutum. Glob Vet 8:197-204

Babak N, Reza IM, Ali S (2012b) Effects of Rheum rebis extract on the blood parameters and responses of Rutilus frisil kutum under heat stress. Glob Vet 8:222-228

Bain BJ, Lewis SM, Bates I (2006) Basic haematological techniques. In: Lewis SM, Bain BJ, Bates I (eds) Dacie and Lewis practical haematology, 10th edn. Churchill Livingstone Elsevier, Philadelphia, pp 26-54

Bhaskar M, Govindappa S (1985) Physiological and metabolic patterns in muscle of fish, Tilapia mossambica on acclimation to altered $\mathrm{pH}$. Ambio 14:349-351

Blaxhall PC, Daisley KW (1973) Routine hematological methods for use with fish blood. J Fish Biol 5:771-781

Bricknell IR, Bowden TJ, Bruno DW, MacLachlan P, Johnstone R, Ellis AE (1999) Susceptibility of Atlantic halibut, Hippoglossus hippoglossus (L.), to infection with typical and atypical Aeromonas salmonici9da. Aquaculture 175:1-13

Das PC, Ayyappan S, Jena JK (2006) Haematological changes in the three Indian major carps, Catla catla (Hamilton), Labeo rohita (Hamilton) and Cirrhinus mrigala (Hamilton) exposed to acidic and alkaline water pH. Aquaculture 256:80-87

Dominguez M, Takemura A, Tsuchiya M (2005) Effects of changes in environmental factors on the non-specific immune response of Nile tilapia, Oreochromis niloticus L. Aquacult Res 36:391-397 
Du WX, Olsen CW, Avena-Bustillos RJ, McHugh TH, Levin CE, Mandrell R, Friedman M (2009) Antibacterial effects of allspice, garlic, and oregano essential oils in tomato films determined by overlay and vapor-phase methods. J Food Sci 74:390-397

Elahee KB, Bhagwant S (2007) Hematological and gill histopathological parameters of three tropical fish species from a polluted lagoon on the west coast of Mauritius. Ecotoxicol Environm Saf 68:361-371

Ellis AE (1990) Lysozyme assays. In: Stolen JS, Fletcher TC, Anderson DP, Roberson BS, Van Muiswinkel WB (eds) Techniques in fish immunology. SOS Publications, New Jersey, pp 101-103

El-Sayed AFM (2006) Tilapia culture. CAB International, Wallingford

Evans JJ, Shoemaker CA, Klesius PH (2003) Effects of sublethal dissolved oxygen stress on blood glucose and susceptibility to Streptococcus agalactiae in Nile tilapia Oreochromis niloticus. J Aquat Anim Health 15:202-208

Faggio C, Fazio F, Marafioti S, Arfuso F, Piccione G (2015) Oral administration of Gum Arabic: effects on haematological parameters and oxidative stress markers in Mugil cephalus. Iran J Fish Sci. 14(1):60-72

Fazio F, Marafioti S, Arfuso F, Piccione G, Faggio C (2013) Influence of different salinity on haematological and biochemical parameters of the widely cultured mullet, Mugil cephalus. Mar Freshw Behav Physiol. 46(4):211-218

Ghanbari M, Jami M (2012) Long-term effects of water pH changes on hematological parameters in the common carp (Cyprinus carpio L.). Afr J Biotechnol 11:3153-3159

Kikuzaki H, Hara S, Kawai Y, Nakatani N (1999) Antioxidative phenylpropanoids from berries of Pimenta dioica. Phytochemistry 52:1307-1312

Kiron V (2012) Fish immune system and its nutritional modulation for preventive health care. Anim Feed Sci Tech $173: 111-133$

Li CC, Chen JC (2008) The immune response of white shrimp Litopenaeus vannamei and its susceptibility to Vibrio alginolyticus under low and high pH stress. Fish Shellfish Immun 25:701-709

Mars B (2007) The desktop guide to herbal medicine: the ultimate multidisciplinary reference to the amazing realm of healing plants. In: Mars B (ed) Basic health publications. Laguna Beach, California, pp 28-29

Miron DS, Pretto A, Crestani M, Glusczak L, Schetinger MR, Loro VL, Morsch VM (2008) Biochemical effects of clomazone herbicide on piava (Leporinus obtusidens). Chemosphere 74:1-5

Montero D, Marrero M, Izquierdo MS, Robaina L, Vergara JM, Tort L (1999) Effect of vitamin E and C dietary supplementation on some immune parameters of gilthead seabream (Sparus aurata) juveniles subjected to crowding stress. Aquaculture 177:269-278

Nayak Y, Abhilash D (2008) Protection of cyclophosphamide induced myelosuppression by alcoholic extract of Pimenta dioica leaves in mice. Pharmacologyonline 3:719-723

Nayak Y, Abhilash D, Vijaynarayana K, Fernandes J (2008) Antioxidant and hepatoprotective activity of Pimenta dioica leaves extract. J Cell Tissue Res 8:1571-1576

Nussey G, Vuren JHV, Preez HHD (2002) The effect of copper and zinc at neutral and acidic pH on the general haematology and osmoregulation of Oreochromis mossambicus. Afr J Aquat Sci 27:61-84

Pitaksong T, Kupittayanant P, Boonanuntanasarn S (2013) The effects of vitamins C and E on the growth, tissue accumulation and prophylactic response to thermal and acidic stress of hybrid catfish. Aquacult Nutr 19:148-162

Quade MJ, Roth JA (1997) A rapid, direct assay to measure degranulation of bovine neutrophil primary granules. Vet Immunol Immunopathol 58:239-248

Roberts H, Palmeiro BS (2008) Toxicology of aquarium fish. Vet Clin N Am Food Anim Pract 11:359-374

Siwicki AK, Anderson DP (1993) Immunostimulation in fish: measuring the effects of stimulants by serological and immunological methods. Abstract and techniques manual presented at the nordic symposium on fish immunology, Lysekil, Sweden

Teixeira CP, Barros MM, Pezzato LE, Fernandes AC, Koch JFA, Padovani CR (2012) Growth performance of Nile tilapia, Oreochromis niloticus, fed diets containing levels of pyridoxine and haematological response under heat stress. Aquacult Res 43:1081-1088

Wepener V, Vanvuren JHJ, Dupreez HH (1992) Effect of manganese and iron at a neutral and acidic pH on the hematology of the banded tilapia (Tilapia sparrmanii). Bull Environ Contam Toxicol 49:613-619

Yada T, Ito F (1997) Difference in tolerance to acidic environments between two species of tilapia, Oreochromis niloticus and O. mossambicus. Bull Natl Res Inst Fish Sci 9:11-18

Yılmaz S, Ergün S (2012) Effects of garlic and ginger oils on hematological and biochemical variables of sea bass Dicentrarchus labrax. J Aquat Anim Health 24:219-224

\section{Submit your manuscript to a SpringerOpen ${ }^{\circ}$ journal and benefit from:}

- Convenient online submission

- Rigorous peer review

- Immediate publication on acceptance

- Open access: articles freely available online

- High visibility within the field

- Retaining the copyright to your article

Submit your next manuscript at $>$ springeropen.com 